POSTER SYMPOSIUM

\title{
SURFACTANT REPLACEMENT
}

\author{
Thursday, April 30, 1987; 10:00 A.M. - 12:30 P.M. \\ MARINA BALLROOM 2 \\ (Hotel Convention Center)
}

Moderators: Philip Ballard and Barry Smith

1. CLONING AND PREDICTED STRUCTURE OF HYDROPHOBIC SURFACTANT PROTEIN SPL(Phe). Stephan W. Glasser, Thomas R. Korfhagen, Timothy E. Weaver, Tami Mateos-Pilot, J. Lawrence Fox, Jeffrey A. Whitsett. Dept. of Pediatrics, Univ. of Cincinnati College of Medicine, Cincinnati, $\mathrm{OH}$ and Abbott Laboratories, Abbott Park, IL. (Abstract 1127).

2. EXPRESSION, CHARACTERIZATION AND IN VITRO ACTIVITY OF RECOMBINANT SURFACTANT PROTEIN SP28-36. R. Tyler White, Deborah Damm, Douglas Buckley, Samuel Hawgood, Kaye Spratt, James Schilling, Brad Benson (Spon. by P.L. Ballard). California Biotechnology Inc, Mountain View, $\mathrm{CA}$, and Dept. of Pediatrics and Cardiovascular Research Institute, University of California, San Francisco, CA. (Abstract 1774).

3. 2-YEAR FOLLOW UP OF INFANTS ENROLLED IN A RANDOMIZED TRIAL OF SURFACTANT SUPPLEMENTATION. Michael S. Dunn, Andrew T. Shennan, Elizabeth M. Hoskins, Goran Enhorning (Spon. by Barry Smith). Women's College Hosp., Univ. of Toronto Perinatal Complex, Toronto, Ontario, Canada. (Abstract 1116).

4. SYNERGISTIC RESPONSE OF ANTENATAL BETAMETHASONE AND TRACHEAL INSTILLATION OF CALF LUNG SURFACTANT EXTRACT (CLSE) AT BIRTH. Melinda Kwong, Edmund Egan, Robert Notter. Dept. of Ped., Univ. at Buffalo, SUNY and Univ. of Rochester, NY. (Abstract 1706).

5. A LOW MOLECULAR WEIGHT (LMW) APOPROTEIN (5-12kD) AND PHOSPHOLIPID RECONSTITUTE HUMAN LUNG SURFACTANT ACTIVITY. Susan D. Revak, T. Allen Merritt, Mikko Halman, Charles G. Cochrane. Scripps Clinic \& Research Found, Dept of Immunology, La Jolla, Ca; Univ. of Ca, San Diego, Ca; Univ. of Helsinki, Helsinki, Finland (Abstract 1741).

6. EFFECTS OF PHOSPHOLIPIDS (PL), RECOMBINANT HUMAN SURFACTANT GLYCOPROTEIN (SP28-36) AND HUMAN SURFACTANT PROTEINS (SP5,SP18) ON THE PULMONARY MECHANICS OF PREMATURE RABBITS. Samuel Hawgood, Mureen A. Schlueter, Cynthia L Brown, William H. Tooley, Douglas Buckley, R. Tyler White, Bradley J. Benson. Dept. Ped. \& CVRI Univ. CA San Francisco \& CA Biotech., Mountain View, CA. (Abstract 1686).

7. IMPROVED SURVIVAL IN VERY PREMATURE INFANTS TREATED WITH MULTIPLE DOSES OF CALF LUNG SURFACTANT EXTRACT (CLSE). James W. Kendig, Robert H. Notter, Donald L. Shapiro. Univ. of Rochester School of Medicine, Strong Memorial Hosp., Dept. of Pediatrics, Rochester, NY. (Abstract 1149). 
8. SURFACTANT CLEARANCE IN 3-DAY-OLD RABBITS: EFFECT OF LIPID EXTRACTION AND RESUSPENSION ON CLEARANCE KINETICS OF PHOSPHATIDYLCHOLINE (PC). Andrea Pettenazzo, Steven R. Seidner, Machiko Ikegami, Alan H. Jobe. UCLA School of Medicine, Harbor-UCLA Medical Center, Department of Pediatrics, Torrance, CA. (Abstract 1735).

9. RADIOGRAPHIC FINDINGS ASSOCIATED WITH SURFACTANT TREATMENT. Roger F. Soll, Jeffrey D. Horbar, N. Thorne Griscom, Richard A. Barth, Jerold F. Lucey, H. William Taeusch. Dept. of Pediatrics and Radiology, Univ. of Vermont College of Medicine, Burlington and Harvard Medical School, Boston, MA. (Abstract 1758).

10. EARLY PDA LIGATION IN SURFACTANT TREATED ANIMAL WITH HYALINE MEMBRANE DISEASE (HMD) DOES NOT IMPROVE PULMONARY FUNCTION. Senji Shimada, Tonse Raju, Rama Bhat, Dharmapuri Vidyasagar, Wandra Jones, Haruo Maeta. Univ. of IL Medical Center, Dept. of Pediatrics, Chicago, IL. (Abstract 1755). 